\title{
Andrew I. Port and Julia Torrie - An Appreciation of Editorial Leadership
}

FTER five years of dedicated service, Professor Andrew I. Port (Wayne State
University) and Professor Julia Torrie (St. Thomas University, CAN) step down
from the editorial leadership of Central European History.

The board of the Central European History Society expresses its gratitude and appreciation for Andrew Port's service as editor-in-chief for Central European History. Over the last five years, Andrew tirelessly devoted time and energy to enhance the journal's high standards. Those of us not directly involved in the production of a journal tend to overlook the tasks that comprise an editor's life: vetting submissions, soliciting peer reviews, counseling revisions, placating authors, and beating the drum for good material. To organize forums, design theme issues, and nurture innovative work, an editor must attend conferences, read widely in other fields, and collaborate with colleagues. These tasks entail countless conversations and copious correspondence, whose cumulative time commitment far exceeds the job's description as "supplemental" or "half-time." Producing four issues a year is already a Herculean task in and of itself. Andrew Port, however, took a holistic view of the journal and introduced new features that recast the publication inside and out. The journal's appearance switched from a generic cover to the Berlin paintings of Edward B. Gordon; its articles featured color illustrations; a "Letter from the Editor" opened each issue; abstracts in both English and German accompanied essays; and, not least, he commissioned exhibition reviews - a new genre. Among the many special issues that he ushered into print, the commemoration of the journal's fiftieth anniversary deserves special mention. More than two dozen scholars contributed essays on the history of the journal and the field, thus constituting an important Zeitdokument of our profession's history. These labors paid off: submissions increased and the impact factor rose. We salute the work ethic, entrepreneurial zeal, and intellectual creativity that burnished the journal's good name. A thousand thanks, Andrew, for your exemplary service to the profession and to the field of Central European History.

In the same spirit, we also pay tribute to associate editor Julia Torrie, who managed the journal's book review section for five years. Increased faculty workloads have not made it easy to commission and collect book reviews. It is to Julia's lasting credit that she has maintained the quality and utility of the review section, which consistently captured the latest historiographical trends, thereby providing a panorama of our field's evolving interpretive landscape. Under her tenure, the number of review essays and featured reviews rose significantly, engaging $\mathrm{CEH}$ readers with more substantive assessments of critical research.

Finally, the Central European History Society welcomes the new editor-in-chief, Professor Monica Black (University of Tennessee, Knoxville) and the new associate editor, Professor Mirna Zakic (Ohio University). 